\title{
$\mathrm{PH} 104$
}

\section{La Comisión Europea reconoce la contribución del Museo Cal de Morón a la salvaguardia del patrimonio cultural europeo}

El jurado de los Premios de Patrimonio Europeo/Premios Europa Nostra 2021 ha destacado el aspecto intergeneracional del trabajo de la Asociación Cultural Hornos de la Cal de Morón, propietaria del Museo, así como el exitoso enfoque de la economía circular. La Comisión Europea reconoce con el galardón entregado el pasado 23 de septiembre, dentro de la categoría "Educación, formación y sensibilización", la importante labor de preservación, difusión y conservación de la cultura de la cal en el marco de las acciones sostenibles en Europa. La asociación Hornos de la Cal viene colaborando activamente con el programa de formación del Instituto Andaluz del Patrimonio Histórico desde 2013.

Manuel Gil Ortiz | Museo Cal de Morón

URL de la contribución <http://www.iaph.es/revistaph/index.php/revistaph/article/view/5002>

El proyecto premiado se presentó bajo el título La Cal artesanal de Morón. Recuperación y difusión de sus saberes y bienes asociados en el marco de las acciones sostenibles en Europa y está vinculado, dentro de las áreas previstas en la convocatoria, a las estructuras y sitios de patrimonio industrial. Entre los veinticuatro proyectos reconocidos en 2021 figuran seis españoles: rehabilitación de la torre de las aguas de Besòs (Barcelona) y de la masía Mas de Burot (Horta de Sant Joan, Tarragona); Art-risk, un software de inteligencia artificial aplicado a la restauración preventiva de edificios patrimoniales; Valencia en la memoria, tres refugios de la Guerra Civil; Heritage Hub, compartido con Finlandia; y el Museo Cal de Morón.

\section{Museo Cal de Morón}

La Asociación Cultural Hornos de la Cal de Morón, entidad de carácter privado sin ánimo de lucro, compuesta por siete amigos de la localidad de Morón de la Frontera (Sevilla), es la propietaria del Museo desde el que se ha desarrollado un extenso programa para preservar, conservar y difundir la cultura de la cal en esta zona.

Las actuaciones realizadas han tenido dos vertientes principales: la salvaguarda del patrimonio inmaterial, basada en la actividad de los caleros, y la salvaguarda del patrimonio material, representada en las actuaciones en la aldea Caleras de la Sierra. Estas han consistido
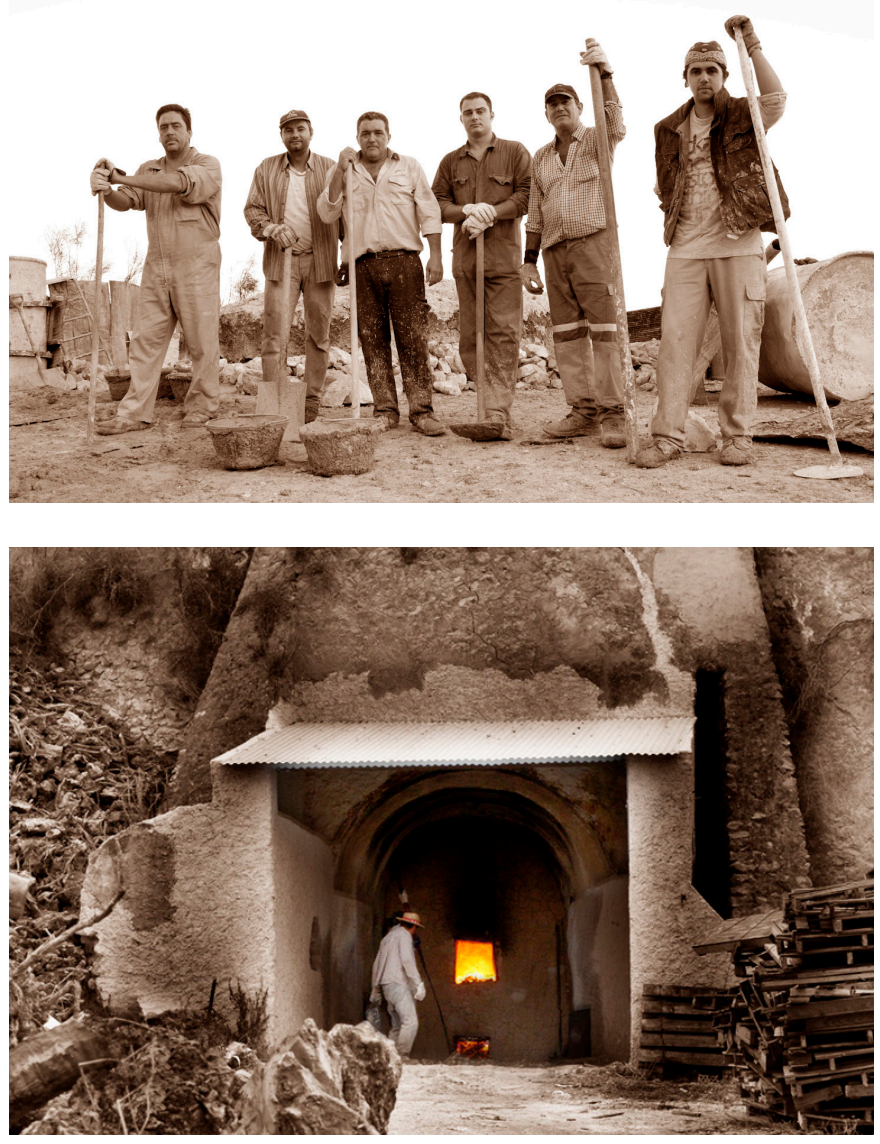

Caleros activos en 2021 y detalle de horno en aldea Caleras de la Sierra | fotos Manuel Gil Ortiz 
en la puesta en valor de los hornos y en actividades de difusión en el Museo. Una de sus actividades principales ha sido conservar y restaurar los bienes inmuebles de la cultura del trabajo y de la vida cotidiana de sus trabajadores relacionados con la producción tradicional de la cal, en colaboración con los caleros artesanos de la zona.

En el Museo Cal de Morón se trabaja intensamente en tres pilares fundamentales: formación, educación y turismo cultural.

> Formación: se ofrecen cursos a profesionales de toda España para recuperar oficios tradicionales relacionados con técnicas de construcción sostenible, especialmente las relacionadas con la cal artesanal. La colaboración en este apartado con el IAPH comenzó en 2013 y en 2021 se van a llevar a cabo un total de 4 cursos dentro del programa de formación anual del Instituto.

> Educación: interesantes visitas guiadas, con el desarrollo de talleres de pintura al fresco para alumnos desde los niveles de primaria a enseñanzas universitarias.

> Turismo: visitas culturales a todos los niveles, en las que se muestra un espacio vivo que nos acerca a la cultura de la cal, una de las señas de identidad más importante de Andalucía. A través de los testimonios y experiencias de los propios caleros, se descubren el procedimiento de elaboración artesanal de la cal, su historia, usos, herramientas e iconografía y la relaciones con los habitantes de la zona.

En la actualidad las diferentes actividades desarrolladas por la asociación apenas reciben apoyo económico institucional, solo una pequeña aportación del Ayuntamiento de Morón de la Frontera.

La sostenibilidad ambiental es fundamental para las actividades de la asociación, ya que se busca ampliar el papel de la cal producida tradicionalmente en la construcción bioclimática. Se trabaja con la naturaleza en lugar de en contra de ella. En colaboración con socios académicos, la asociación lleva a cabo investigaciones sobre las cualidades de absorción de $\mathrm{CO}_{2}$ de la cal, por lo que se pone así de manifiesto su compromiso con la innovación sostenible en el campo de los materiales de construcción.

Este proyecto supone un ejemplo de respuesta a la decadencia y despoblación rural, un problema que está presente en casi toda Europa. La conservación de un paisaje cultural etnográfico, incluido su patrimonio material e inmaterial, declarado por Unesco en 2011 Patrimonio Cultural Inmaterial de la Humanidad. La experiencia ha fijado la población al territorio mediante la creación de un nicho importante de empleo, con una actividad y un producto sostenible desde el punto de vista medioambiental, dado que sus técnicas aprovechan los recursos naturales autóctonos.

La cal tradicional con sus excelentes propiedades como virucida, fungicida, bactericida y su condición de ignífuga, además de facultades de adecuación térmica y aislante, parece ideal para mantener ambientes sanos y desinfectados. Esta eficacia ha sido demostrada a lo largo de la historia y, gracias al trabajo, entre otros, de la Asociación Cultural Hornos de la Cal de Morón, fue inscrita en 1993 en el Inventario de Arquitectura Popular de Andalucía y, en 2009, en el Catálogo General del Patrimonio Histórico Andaluz como BIC, con la tipología jurídica de lugar de interés etnológico. Un año después, en 2010, el Atlas del Patrimonio Inmaterial de Andalucía registró la actividad.

El galardón recientemente concedido impulsará la creación de una red de centros europeos que difunda este patrimonio cultural, que rescate y ponga en valor los hornos históricos ubicados en cada territorio y elabore medidas conjuntas de recuperación y salvaguarda de la cultura de la cal y sus oficios milenarios presente en toda la Unión Europea, especialmente de la ribera mediterránea, cuya principal imagen identitaria debe mucho a este producto en sus distintas aplicaciones en la arquitectura tanto monumental como popular. 